\title{
DULANG MODULE IN DETERMINING THE PROPORTION OF BENGKILAS IN PALEMBANG LIMAS HOUSE
}

\author{
Ibnu Aziz \\ Doctoral Student, Postgraduate Program, Faculty of Engineering \\ Sriwijaya University, Indralaya, Indonesia \\ Department of Architecture Engineering \\ Tridinanti University Palembang, Palembang, Indonesia \\ Ari Siswanto \\ Department of Architecture Engineering \\ Sriwijaya University, Indralaya, Indonesia \\ Ngakan Putu Sueca \\ Department of Architecture Engineering \\ Udayana University, Denpasar, Indonesia \\ Dadang Hikmah Purnama \\ Department of Sociology \\ Sriwijaya University, Indralaya, Indonesia
}

\begin{abstract}
The dulang module is a key measurement system in the construction of Palembang limas house, with a length specification of six dulang per bengkilas, each containing a dish for eight people. A smaller dulang module is also found in Malay standard houses in Malaysia to determine the size of the porch, so than the question arises as to why dulang is used as a measurement base for these two types of Malay houses. This paper presents a number of factors that allow the dulang module to emerge as a porch/bengkilas measurement system. This research uses the PESTLE (Political, Economic, Sociological, Technological, Legal, Environmental) framework as a base for exploration of related interdisciplinary literature. It was found that open culture, maritime economics, collectivism, house technology without nails and metals, Islamic teachings on cleanliness, alms, norms of egalitarianism, wood supply, and windy environment are the factors that encourage the use of the eight-person dulang module as the length measurement system of bengkilas in Palembang limas house.
\end{abstract}

Key words: dulang, module, bengkilas, PESTLE, limas house 
Cite this Article: Ibnu Aziz, Ari Siswanto, Ngakan Putu Sueca and Dadang Hikmah Purnama, Dulang Module In Determining the Proportion of Bengkilas in Palembang Limas House, International Journal of Civil Engineering and Technology, 11(04), 2020, pp.14-23

http://www.iaeme.com/IJCIET/issues.asp?JType=IJCIET\&VType=11\&IType $=04$

\section{INTRODUCTION}

Limas is a traditional house of Palembang, South Sumatra, Indonesia. Limas is a house with a multilevel stilts and an extensive roof. The stilt level facilitates several areas which are referred to as bengkilas. Bengkilas can be said as a porch for the limas house, especially in bengkilas which is at the foremost/lowest position. Usually limas has three or four bengkilas and quite rarely has five bengkilas. Bengkilas functions as an area to receive guests or organize activities that involve many people in the house. Depending on the number of bengkilas, the space for bengkilas usually covers half of the length of the limas house.

The interesting thing is that the size of each bengkilas has been determined by default through the dish module. The dish module is a unit of measurement taken from a square formed by a pattern of eight people sitting around a dulang filled with foods (Fig. 2). The size of this module is square with $260 \mathrm{~cm}$ sides. The length of one bengkilas is six dulang. In homes without additional rooms on the left and right sides, practically the front width of the limas is equal to the length of the bengkilas. This system is also found in at least one other culture, Malaysia Malay culture [1]. In Malaysian Malay culture, one dulang is only for four people with a side of $200 \mathrm{~cm}$.

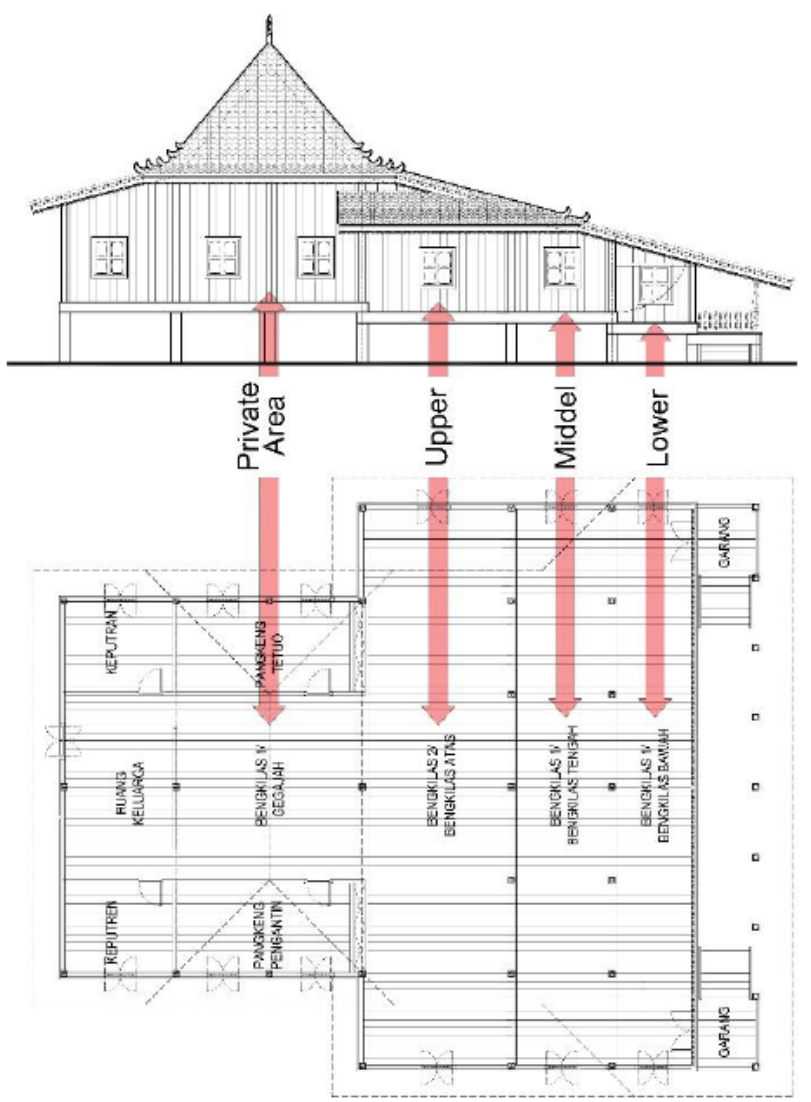

Figure 1. Side and Top View of Limas House with a lower, middle, and upper bengkilas position [2], Redrawn by Aziz, 2020 

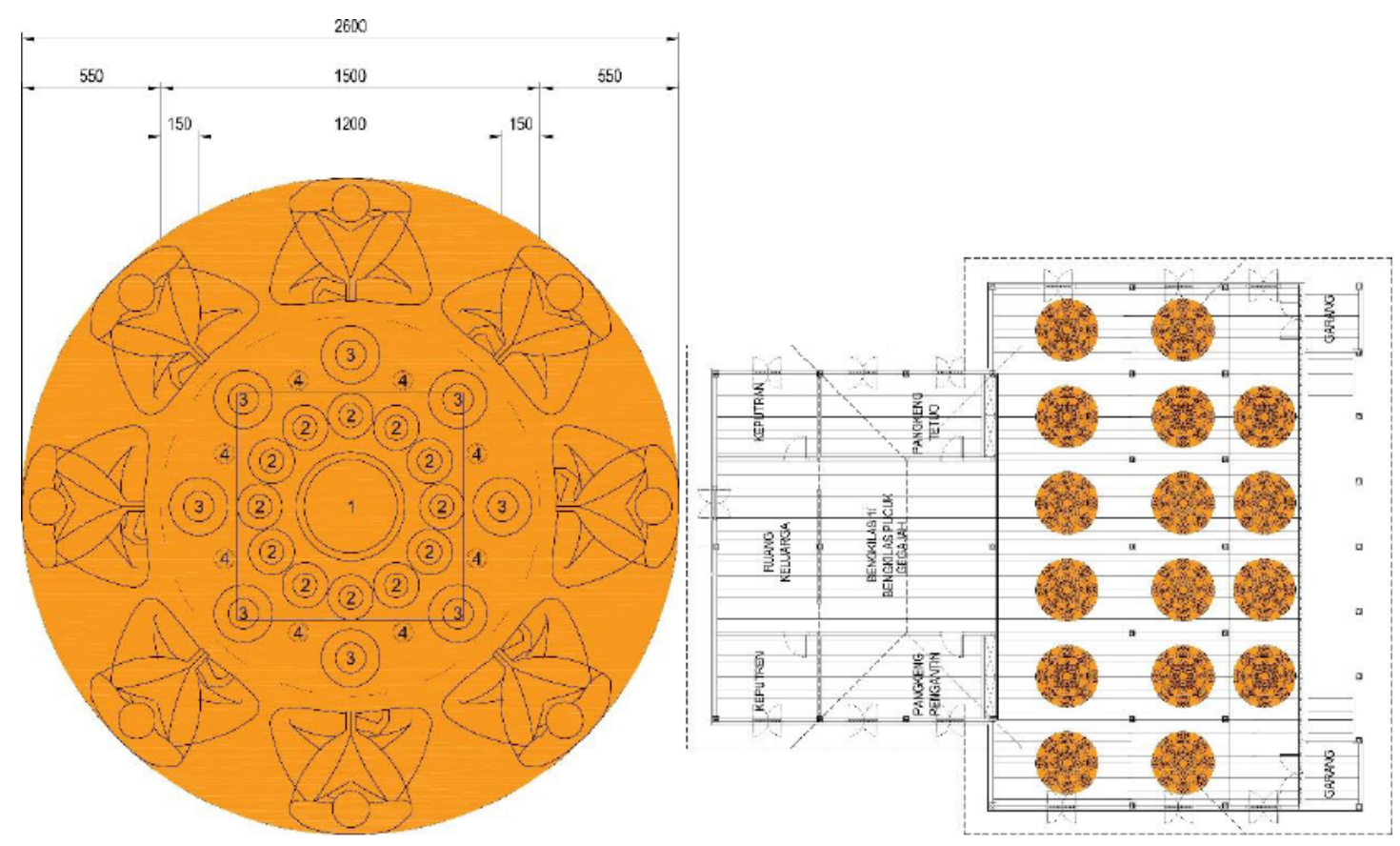

Figure 2. Dish Module (left) and Dish Module Placement on Bengkilas (right). Note: $1=$ dulang for rice $d=43 \mathrm{~cm}, 2=$ plates for side dishes, vegetables, and fruits $d=18 \mathrm{~cm}, 3=$ plates for eating $d=23$ $\mathrm{cm}, 4=$ glasses of drinking water, $\mathrm{d}=$ diameter

The activity of eating around the dulang is actually commonly found in Sumatra (Minang, Belitung) [3] to Lombok (Sasak) [4], but no one has brought it to the level of making it as a module for determining the measurement of an important element in a house. Even so, there is no explanation why bengkilas is measured using the dulang module and why the number of person around each dulang is eight people. As a result, this has become a research gap that needs to be filled. The purpose of this study is to explore the origin of the eight-person dulang module system in determining the size of Palembang limas house with the factor approach.

Because research on the customs of Palembang is still very rarely done, this study refers to a more general cultural hierarchy in order to explore the meaning of dulang in determining the length of benkilas in Palembang limas house. When viewed from the language, Palembang ethnic is one of the Malay sub-ethnic. Malay consists of 59 dialects, divided into three groups: Core Malay (45 languages), Vehicular Malay (11 languages), and Dayak Malay (3 languages). Core Malay is divided into 10 groups. Palembang is a sub-language of Musi which is one of nine sub-languages of Indonesian Malay, one of the Core Malay groups [5]. Politically, the Palembang ethnic group identified themselves as part of the Malay ethnic group [6]. Therefore, it can be understood that many elements commonly found in Malay culture will also be found in Palembang culture with slight variations, such as in the case of the differences between bengkilas and porches. The dulang module is also used by Malaysia Malay ethnic in a smaller size than Palembang Malay, which is for a portion of four people, in determining the size of the porch [1]. For this reason, Malay culture is generally used as a source of reference for achieving research objectives.

\section{THEORITICAL BASE}

An architectural form can emerge and influenced by many factors. An architectural form can emerge because it is influenced by art [7], collective consciousness [8], religion [9], nature [10], architectural styles from other cultures [11], and socio-politics and technology [12]. 
Basically, all things that can arouse human imagination can be a source for the emergence of an architectural feature. Even so, a framework is needed to comprehensively review the factors that are the origin of an architectural form. The management literature provides many of these frameworks. The most widely accepted framework in academic literature is PESTLE [13], which stands for Political, Economic, Sociological, Technological, Legal, and Environmental. PESTLE in architecture is generally used prospectively to identify risks from the environment and to take strategic steps [14]. Even so, there is no obstacle in using it for a retrospective analysis framework because the aspects covered by PESTLE are aspects that also affect various aspects of human life, including the decision to take the system of eightperson for one dulang.

\section{METHOD}

This study uses a literature study approach. The researcher uses the PESTLE framework to explore aspects of Malay culture. The researcher collects literatures relating to aspects of each PESTLE element and sees their connection with the purpose of understanding their relation to the dish module to determine the dimensions of the bengkilas space. The literature explored was obtained from the Google Scholar search engine.

\section{RESULTS AND DISCUSSION}

The following table shows a number of factors that were found to influence Palembang Malay decision in designing bengkilas with the dulang system. The results on each aspect are discussed directly with the section that is most relevant to the research objectives

Table 1 Factors That Become the Origins of the Formation of Bone Module in Bengkilas of Palembang Limas House

\begin{tabular}{|c|c|}
\hline Dimension & Factor \\
\hline Political & Open politics \\
\hline Economics & Maritime economy \\
\hline Sociological & Collectivism \\
\hline Technological & Flexible (Knock-down) house, zinc material \\
\hline Legal & Islamic norms on cleanliness, alms giving, and egalitarianism \\
\hline Environmental & Woods availability, strong winds \\
\hline
\end{tabular}

\subsection{Open Politics Factor}

The open politics system requires the society of Palembang to facilitate many people in enjoying banquets, both known and foreign people/guests. Malay society is a society with open politics. This is reasonable given that Malay geography in the Ocean crossing of Indonesian archipelago and Malacca Strait. Various nations came throughout history to carry out trade activities and interact socio-culturally with the Malay society [15]. It is very important for Malay society to be open to foreign nations to get the maximum benefit from trading activities

\subsection{Collective Social System Factor}

Overall, Malay ethnic and ethnic in the tropical region in general are classified as ethnic with a collective social system [16]. Collectivism is characterized by the priority of harmony and close social relations between members in a group [17]. In terms of architecture, the collective social system has a semi-public space that is wider than the private space, in 
contrast to the individual social system that prioritize private space [18]. Spacious public space is reflected in the provision of large space for bengkilas, so as to accommodate many people in one house. The use of the eight-person dulang module is also in accordance with the collective system because it maximizes the possibility of the number of people who can be accommodated for one food container that can still be carried by one person from the kitchen to bengkilas.

The use of the eight-person dulang module instead of four as a form of collectivism can also be drawn from the results of research on the dulang used in the megibung tradition in Bali and Sasak [19]. Kasih et al [19] stated that in the past, the Megibung dish module in the Sasak and Balin tribe was for eight people, but in the present it is only for four people. This can be interpreted as the fading of togetherness in a society where fewer people want to eat together. That is, eight people contain more togetherness than four people.

This explanation can then be harmonized with the motto "Batanghari Sembilan" which is the motto of Palembang society, describing the existence of eight rivers that are branches of the Musi river. This motto is a modern attachment to the principle of togetherness based on eight people in Palembang's collectivism system.

\subsection{Flexible House and Material Technology Factors}

One distinctive characteristic of Malay houses is the joint system without nails. Systems without pegs were raised not because of the absence of nails but because iron nails already exist for quite a long time. At least there was a large nail industry in Palembang in 1798 [20]. A nail-free joint system is used because Malay houses are made to be flexible. With the joint without nails, the house can be removed easily when the house wants to be moved. This moving house system is supported by lightweight building materials and allows several people to carry them. There is a special ceremony in the Malay society to move houses from one village to another. The practical reason could be due to house sales, birth, or death [21] but this can be rooted in maritime culture which generally views boats as homes and can be moved around. The view that even houses can be moved can come from the maritime thinking like this.

The flexibility of a house can support the dulang system at least in the moral aspect. The existence of bengkilas with the dulang system ensures that after the house has been moved, the society working together can immediately be given a meal as a token of gratitude from the residents of the house. The large bengkilas room and its clear dulang modules allow the community to immediately enter and enjoy the banquet and be accommodated entirely. In one limas house with a good module system, it can accommodate as many as 192-240 people [22], enough to entertain the population in a small village.

The second important technology is the technology of materials, especially zinc metal. The presence of zinc which is used to make dulang allows dulang to withstand more food loads, better than perishable wood or rare copper. Zinc material technology then allows foods to be served by one person who carries a tray with plenty of food that is enough for eight people, rather than four. Although there has been cheap technological support for the use of eight-person dulang, some Malay traditions such as in Malaysia or bedulang eating in Belitung still use the four-person dulang module [23]. Therefore, there needs to be a norm that encourages the use of eight-person dulang and this can be sourced from religious teachings. 


\subsection{Islamic Norms/Teachings Factor}

Although Hinduism seems to have been embraced by the Malay tribe in the Jambi Malay Kingdom during the Srivijaya era, the Malay tribe are now strongly identified with Islamic teachings. Certain aspects of Islamic teachings provide rules that are relevant to communal banquet activities in the house. This includes teachings on cleanliness, sadaqah, and nonhierarchical norms in social structures [24]. Even the teachings of Islam ordered the people to fast at certain times, one of them as an expression of empathy for members of the society who lack food.

Islamic teachings teach about cleanliness as part of faith so that the inside of the house, especially the floor, is kept clean [25]. Malay custom and generally the tribes in the Austronesian region do not use shoes when in the house [26]. This is due to the wet climate which causes dirt to stick to the shoes and if the shoes are brought into the house, it will cause the floor to become dirty. In Malay houses, there are jars filled with water in front of the stairs so that people who enter have to first wash their feet before entering the house. A house with clean wooden floors allows people to sit and gather to enjoy food communally.

In addition, the teachings of Islam also give priority to the meaning of social contribution to the society. Individual contributions to society take several forms, namely zakat, infaq, alms, and waqf. Zakat is a compulsory contribution in various forms for economic welfare while infaq are voluntary in financial form. Waqf is voluntary assistance in the form of nonfinancial which is more permanent and high-value such as land or buildings for public purposes such as health, education, and infrastructure [27]. Alms is a simple form of assistance including food, money, goods, and even a smile.

Collective banquets can be seen as alms for homeowners to assert that they are devout Muslims. In this case, the dulang module design guarantees that the house can facilitate alms in the form of banquets for the community, especially those with lower socio-economic status. This alms can be given at certain moments such as birth, circumcision, khataman, marriage, pilgrimage, and death.

Islamic teachings also have high egalitarian values related to social status. In the Islamic view, social status is an only human production while the degree of someone in God's eyes is only judged by their piety. In communal eating activities, everyone's social position disappears. The circular dulang design gives a more egalitarian meaning because no one has a special position in this design. In the circular shape, everyone is face to face and there is no end in this circle, indicating equality.

Islamic teachings support eight people as the number of eating participants, rather than four, as the basis of togetherness. Muslim Historical Hadith states "food for one person is enough for two people, food for two people is enough for four people, food for four people is enough for eight people" (HR Muslim No 3836) [28]. This reason is used to explain the tradition of Bajamba eating in Minangkabau which also uses a dish for eight people [3].

Egalitarianism also determines why a circular circle system (Fig. 4(a)) is used rather than an elongated system. In the Sundanese bortram model and Filipinos Kamayan models, participants sit on the side of a dish that extends on the floor on a banana leaf without a special container (Fig. 4(b)). This system is less egalitarian because food portions are less evenly distributed. The elongated system on a table that is common in modern culture allows even distribution of food but does not encourage egalitarianism because there are people with special positions at the ends of the table (Fig. 4(c)). Although a perfect egalitarian system can be realized in a circular serving system that holds an unlimited number of participants (Figure 4 (d)), This system is impractical and impossible to materialize because it will take up a very 
large space and most of the space is just empty space to accommodate a circle and instead separates the physical and social distance between participants. This room can be filled with additional participants but will cause the same problems with the bortram system. The eightperson dulang system can be seen as the most reasonable system to be able to minimize the space to accommodate as many participants as possible so that social interaction is still possible. Intense social interaction occurs because the distance between the participants is close together and participants do not need to look sideways to talk to the next person. A comparison of these egalitarian presentation systems is shown in the following figure.

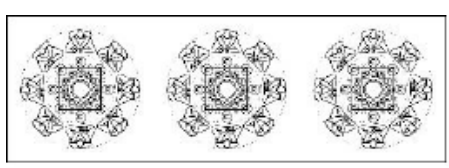

(a)

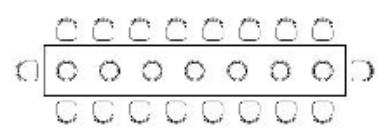

(c)

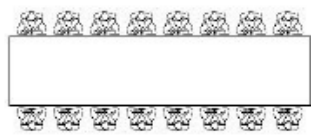

(b)

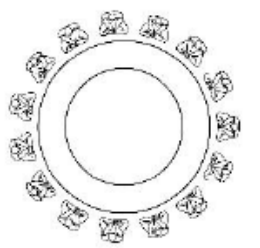

(d)

Figure 4. Various Egalitarian Food Serving Systems: (a) a dulang system with 24 people surrounding three dulang, (b) a bortram system with 16 people divided on two sides of the dish that is spread out, (c) a table system with 18 people divided on four sides of a table with seven dish plates, (d) a perfect circle system with 15 people surrounding a circle with an empty space in the middle

\subsection{Wood Availability and Windy Environment Factor}

As an ethnic group in a tropical country, wood availability with various variations and qualities enables the Malay community to use it to build houses. Wood has the tendency to elongate because it grows vertically. As a result, the simplest wood-based houses are built with boards or beams with a large length and width ratio. The ratio of the length and width of the limas floor is $6: 1$ because in one dish row there are six dulang. This comparison seems to be sourced from a common proportion of the size of wood to build a floor or at least, is a fraction of that proportion. The point that the elongated form of bengkilas followed the abundant wood availability in the living environment. If the stone was abundant, it was likely that the proportion of length to width of bengkilas will be much smaller because these materials are smaller in size and tend to not elongate.

Swamp or windy coastal environment is a common environment of the Malay society. Malay people live in lowland areas in Sumatra, Semenanjung and Kalimantan. This environment facilitates its maritime or riverine culture. In such an environment, an extensive roof is important enough to have to protect occupants from the weather such as rain and wind. The limas house is a Malay house with the most extensive roof. The size of the roof pushes the house to be wider in order to hold the roof structure so that the roof looks bigger than the body of the house [29]. The consequence of a wide house is the need for large spaces and this space will suppress psychologically for residents with small number [30]. The atmosphere can be too quiet and passive. The presence of many people in the house can help 'warm' the house and create an lively atmosphere. As a result, wind factors can push communal activities such as banquets in the house. 


\section{CONCLUSIONS}

The use of the eight-person dulang module to determine the length of bengkilas in Palembang limas house, its emergence seems to be driven a number of factors. Open politics system, collective social system, flexible house technology, and windy environment determine the emphasis on the extension of the number of modules. Maritime economy encourages the habit of making banquets. Metal technology encourages the use of dulang as an adequate banquet container for eight people. This is supported by norms in Islamic teachings that encourage the selection of a round shape for dulang and the placement of eight people around one dulang. The woody tropical environment encourages elongated bengkilas. Overall, these factors produce the encouragement for a large-scale banquet using an eight-person dulang module lined up in an elongated pattern.

Although the results of this study do not explain why limas houses have bengkilas (multilevel porch) rather than porches like Malay houses in general, this study fills the research gap as to why each bengkilas is specifically determined using the elongated pattern and the eight-person dulang module. Further research can be carried out to determine the reasons why bengkilas are arranged in multilevel manner in a limas house. Previous hypotheses assume that this is due to the social stratification of the Palembang society [31], as in the case of the Banjar ethnic's Bubungan Tinggi House [32], but this theory contradicts the fact that the top to bottom bengkilas is the same size and the dulang module is used to distribute food evenly. If the social stratum system is used, the length of the bengkilas will be different where the shortest one should be at the top to facilitate the number of high social strata which is certainly less than the low social strata.

The factors found in this research, especially the role of egalitarian Islamic religion, also oppose this theory. The presence of bengkilas appears to be more related to the economic ability of the homeowner and the society's need to have a semi-public space when establishing a village in the forest. It is also possible that the level of bengkilas aims to accentuate buildings from the surrounding environment so as to facilitate society gathering. The multilevel model facilitates construction and also increases security compared to high stilt models such as the Dayak betang house.

However, a more thorough historiography research should be used and this becomes a limitation in this research. Historical research is expected to be able to reveal the main reasons from the many reasons that this research has found, or find new reasons that determine how bengkilas was built with the eight-person dulang module system.

\section{REFERENCES}

[1] Ariffin, S. I. Made to Order - A Place Called Home. In S. R. Ju (Ed.), Southeast Asian Houses: Expanding Tradition. Seoul: Seoul Selection. 2017.

[2] Anggraeni, D. W., \& Mustika, S. Bentukan massa dan arsitektur pada rumah limas Palembang Hasyim Ning dengan pendekatan akulturasi. Jurnal Arsitektur Komposisi, 12(1), 2018, pp. 1-14.

[3] Wirdanengsih. Makna dan Tradisi-Tradisi dalam Rangkaian Tradisi Khatam Qur'an Anak-Anak di Nagari Balai Gurah Sumatera Barat. Gender Equality: International Journal of Child and Gender Studies, 5(1), 2019, pp. 9-24.

[4] Hardjosinggih, S., \& Anggoro, R. Galeri Kebudayaan Lombok di Kuta, Lombok. Jurnal EDimensi Arsitektur, 4(2), 2016, pp. 129-136.

[5] Glottolog. Malayic Language Tree, Retrieved March 28, 2020, from https://glottolog.org/resource/languoid/id/mala1538 
[6] Syawaludin, M., Fikri, M., \& Zalpa, Y. Malay Political Tradition: The Appointment and Succession Analysis of The Sultanate of Palembang Darussalam. Society, 7(2), 2019, pp. 213-232.

[7] Yang, C. Cultivating Sentiment and Soul and Poetically Living: The Creation Thought and Aesthetic Features of Ancient Chinese Garden Architecture. Advances in Social Science, Education and Humanities Research, 283, 2019, pp. 976-978.

[8] Heravi, H., Falamaki, M. M., \& Tahaei, S. The Representation of the Mother Archetype in the Historical Architecture of Iran Based on Jung's Views. Bagh-e Nazar, 16(75), 2019, pp. 5-16.

[9] Kosinski, W. Outline of Past Landscape Architecture influenced by Tao - Based on Examples Selected from Chinese Metropolises. Forma, 36, 2018, pp. 323-334.

[10] El-ghobashy, S., \& Mosaad, G. Nature Influences on Architecture Interior Designs. Procedia Environmental Sciences, 34, 2016, pp. 573-581.

[11] Kim, A. A., \& Luchkova, V. I. Assimilation of traditional architecture influenced by the imported styles. ITU AZ, 15(3), 2018, pp. 71-80.

[12] Han, N. N., \& Kurniawan, K. R. Brutalism: The and Technological Effect on Postcolonial Modern Architecture in Indonesia. In E3S Web of Conferences, 65, 2018, pp. 1-9.

[13] Ulubeyli, S., \& Kazanci, O. Holistic sustainability assessment of green building industry in Turkey. Journal of Cleaner Production, 202, 2018, pp. 197-212.

[14] Anwar, M., Gill, A. Q., \& Beydoun, G. Using Adaptive Enterprise Architecture Framework for Defining the Adaptable Identity Ecosystem Architecture. In Australasian Conference on Information Systems, 2019, pp. 890-900.

[15] Husin, W. An Introductory Study on The Malay Work Ethics and Business Culture in Malaysia. Advanced Science Letters, 23(1), 2017, pp. 585-588.

[16] Sheth, J. Individualism and Collectivism. In Genes, Climate, and Consumption Culture, 2017, pp. 153-186.

[17] Liu, S. S., Morris, M. W., Talhelm, T., \& Yang, Q. Ingroup vigilance in collectivistic cultures. PNAS, 116(29), 2019, pp. 14538-14546.

[18] Habeck, J., \& Belolyubskaya, G. Fences, private and public spaces, and traversability in a Siberian city. Cities, 56, 2016, pp. 119-129.

[19] Kasih, L. S., Bayu, G. W., \& Jayanta, I. N. L. The Ethnopedagogy Study on the "Megibung" Tradition in Karangasem. Jurnal Filsafat Indonesia, 2(3), 2019, pp. 103-109.

[20] Taal, S. The limas house of Palembang. In R. Schefold, P. Nas, \& G. Domenig (Eds.), Indonesian Houses: Volume 2: Survey of Vernacular Architecture in Western Indonesia, NUS Press, 2, 2008, pp. 363-390.

[21] Wazir, Z. A., \& Indriani, I. Vernacular Answers to Spatial Needs of Human Activities: Indonesian Houses. Dimensi: Journal of Architecture and Built Environment, 46(2), 2019, pp. 141-154.

[22] Aziz, I., Siswanto, A., Sueca, N. P., \& Purnama, D. H. The Tradional Architecture of Palembang Limas House Evaluation of Physical Proportion of Palembang Limas House with Three Bengkilas in Seberang Ulu Palembang. International Journal of Engineering and Advanced Technology, 9(1), 2019, pp. 3631-3635.

[23] Wihardyanto, D., \& Sherlia. Study on Spatial Characteristics on Rumah Panggong in Sijuk District, Bangka Belitung. Dimensi: Journal of Architecture and Built Environment, 45(1), 2018, pp. 93-99.

[24] Rizal, H., \& Amin, H. Perceived Ihsan , Islamic egalitarian and Islamic religiosity towards charitable giving of cash waqf. Journal of Islamic Marketing, 8(4), 2017, pp. 669-685. 
[25] Hirsch, H. Footwear: Manners, Rituals, Culture and Fashion in Early Islam. Antropologija, 17(2), 2017, pp. 37-50.

[26] Tan, S., Horobin, H., \& Tunprasert, T. The lived experience of people with diabetes using off-the-shelf prescription footwear in Singapore : a qualitative study using interpretative phenomenological analysis. Journal of Foot and Ankle Research, 12(19), 2019, pp. 1-12.

[27] Setyaningsih, P., Aziz, R., \& Hadiyati, P. Analysis of Ziswaf, Production Index and Sharia Stock Index on Economic Growth. Jurnal Pasar Modal Dan Bisnis, 1(2), 2019, pp. 221-242.

[28] Al-Albani, M. Ringkasan Shahih Muslim. Jakarta: Gema Insani Press, 2005.

[29] Wir'aeni, R. Educational Values on the Architecture of Bale Sasak Traditional Houses at Limbungan Village East Lombok West Nusa Tenggara. Jurnal Pendidikan Seni Rupa, 2017, pp. 167-175.

[30] Farmaki, A., \& Stergiou, D. P. Escaping loneliness Through Airbnb host-guest interactions. Tourism Management, 74, 2019, pp. 331-333.

[31] Setyawati, D., Sariyatun, \& Suryani, N. Ilir and Uluan: Polarization and Hierarchy of Socio-Political Leadership of Malay-Java in Palembang Sultanate in the 19th Century. Advances in Social Science, Education and Humanities Research, 154(Icclas 2017), 2018, pp. 139-143.

[32] Aqli, W. Anatomi Bubungan Tinggi sebagai rumah tradisional utama dalam kelompok rumah Banjar. NALARs, 10(1), 2011, pp. 71-82. 